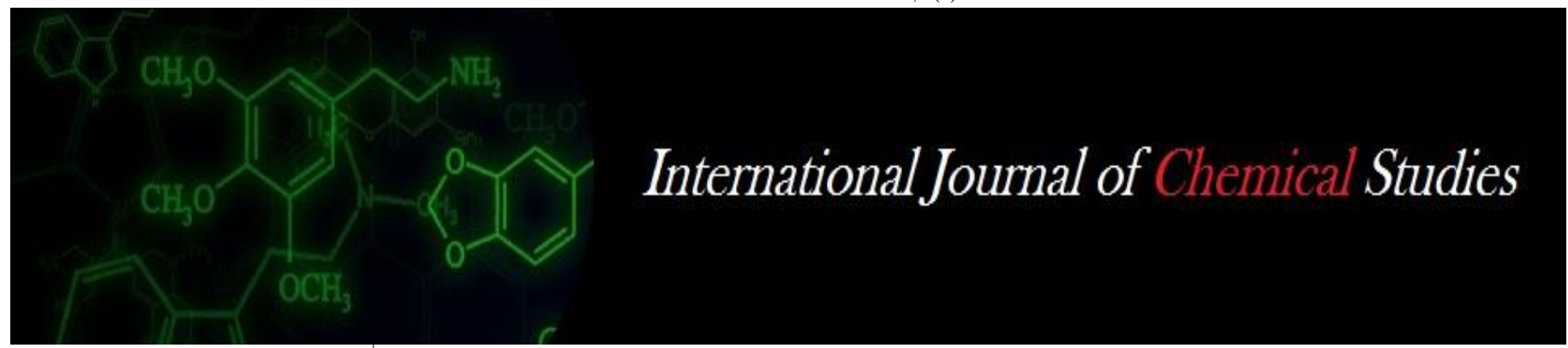

P-ISSN: 2349-8528

E-ISSN: 2321-4902

www.chemijournal.com

IJCS 2020; 8(6): 2597-2600

(C) 2020 IJCS

Received: 07-09-2020

Accepted: 17-10-2020

Anju Rani

Research Scholar, CSKHPKV

Palampur, Kangra, Himachal

Pradesh, India

Sangita Sood

Prof and Head, CSKHPKV

Palampur, Kangra, Himachal

Pradesh, India

Corresponding Author:

Anju Rani

Research Scholar, CSKHPKV

Palampur, Kangra, Himachal

Pradesh, India

\section{Development and quality evaluation of Pancakes prepared by utilizing Field Pea (Pisum sativum var. arvense) grown in Himachal Pradesh}

\author{
Anju Rani and Sangita Sood
}

DOI: https://doi.org/10.22271/chemi.2020.v8.i6ak.11175

\begin{abstract}
The research was conducted with the aim to develop and evaluate the acceptance of healthy Pancakes by utilizing Field pea (Pisum sativum var. arvense) grown in Himachal Pradesh. Pancake or Besan ka Cheela or Besan Chilla is one of the most popular breakfast snacks in Northern India. It is a crispy, quick to make, nutritious, low calorie and protein rich snack made of besan or chickpea flour and mild spices. In the present study Pancakes were developed by incorporating field pea flour in besan in different ratios and were evaluated both subjectively and objectively. The sensory evaluation was done with 15 panel members using Nine Point Hedonic Scale. The result shows that the developed Pancakes were highly acceptable. The moisture, ash, crude protein, fat, crude fiber, carbohydrate and energy content of the developed Pancakes was found in the range of 4.93-7.49, 1.57-3.07, 12.56-16.28, 13.18-27.11, 1.05-6.53, 42.41-55.67 per cent and 438.55-505.37 Kcal/100 g respectively.
\end{abstract}

Keywords: Pancakes, breakfast snacks, nutritious, sensory evaluation, nine point hedonic scale

\section{Introduction}

Breakfast is the most important meal of our daily diet. In this era of urbanization everyone is skipping the most important part of their daily diet. People are ignoring their first meal of the day due to their busy schedule but they are unaware of the consequences of skipping their breakfast. This habit of skipping breakfast may lead to development of metabolic disorders like diabetes mellitus, cardio vascular diseases, obesity and so on. An attempt was made to prepare healthy and quick to make Pancakes. Pulses are a rich source of protein and play a significant role in correcting the prevalent malnutrition in countries like Bangladesh and India (Singh et al., 2015). Among the pulses, field pea (Pisum sativum L.) is an important grain legume in Asia, Europe, North America, Japan and Australia but in Bangladesh, field pea has the potential to be a major pulse crop within a few years (BBS, 2016) ${ }^{[2]}$. It is highly nutritive which contains high proportion of digestive protein (20 to 22.5\%) (Singh et al., 2015). Pulses are rich in macronutrients such as proteins (usually 21-26\%), carbohydrates and are low in calories and fat (Marinangeli and Jones 2011) ${ }^{[5]}$. Pulse proteins can be used in gluten-free products, including muffins and edible biodegradable films (Shevkani and Singh 2014; Shevkani and Singh 2015) ${ }^{[10,9]}$. Dietary fibre (8-28\% in concentration) as a bioactive component of pulses is another area of interest, which depends on the variety, species and processing methods used.

The smooth, green- and yellow-seeded varieties are used for human consumption as dry split field pea. Field pea have high levels of essential amino acids, lysine and tryptophan, which are usually low in cereal grains. Consequently, field pea can supplement the low amount of protein present in food and feed processed from cereal grains. These are used as protein concentrates for livestock and are popular pigeon feeds. Field pea flour is valued due to its unique functional properties besides being cherished as a source of vegetable protein. The use of vegetable proteins as functional ingredients in the food industry is increasing tremendously and special attention has been given to the use of field pea since they are already an accepted part of the human diet throughout the world. The viscosity of slurried pea flours makes them useful in aqueous food systems. 
The nutritional, agronomic as well as economic benefits of dry pea are substantial (Muramoto et al. 2011; Chen et al. 2012; Miller et al. 2015) ${ }^{[7,3,6]}$. Dry pea is an important source of protein, complex carbohydrates, vitamins, and minerals (Wang and Daun 2004; Hood Niefer et al. 2012) ${ }^{[12,4]}$.

\section{Material and Methods}

The study was carried out in the Department of Food Science Nutrition and Technology, College of Community Science, CSKHPKV, Palampur during 2016-2020.

\subsection{Procurement of Materials}

The grains of selected crop, field pea (Pisum sativum var. arvense) were collected from local landeries of the Regional Research Station, Sangla (Tribal area of Himachal Pradesh). The procured samples were cleaned manually for removing any kind of adhering dust, debris and foreign particles. The grains were then ground into a fine powder with the help of stainless steel mixer grinder and stored in airtight food-grade polyethylene terephthalate containers at ambient temperature for further analysis. The other required materials were purchased from the local market of Palampur. The analytical grade chemicals and reagents were used for precision and the analysis was carried out in triplicate to minimize the determinants error.

\subsection{Preparation of Product}

Pancakes were prepared in the Food laboratory. All required ingredient were measured separately. All the four formulations were prepared separately (Table 1).

\section{Flowchart for the preparation of Pancakes}

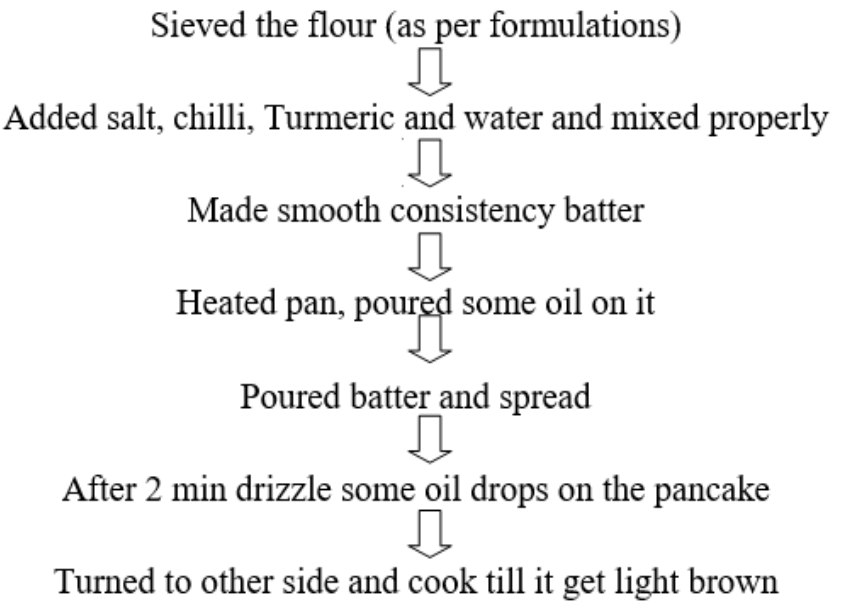

\subsection{Chemical analysis of Pancakes}

The chemical composition of the Pancakes was determined by following the standard procedure as laid down in literature of AOAC (2010) ${ }^{[1]}$. The fat content was analyzed by means of Soxhlet extraction method, and protein content was determined by the Kjeldahl method. The ash content of the samples was estimated by means of Muffle furnace operated at a temperature of $550{ }^{\circ} \mathrm{C}$.

\subsection{Sensory evaluation}

The samples were evaluated organoleptically for checking the consumer's acceptability. The parameters like colour, flavor, texture, taste and overall acceptability were analyzed at Nine Point Hedonic Scale Performa. The samples were evaluated by a panel of semi-trained judges from the department. The index of acceptance (IA\%) was measured by using the equation given by Schumacher et al. 2010 Index of Acceptance (\%) $=M / 9 * 100$

where, $\mathrm{M}=$ the average of evaluations carried out by the sensory panel

\subsection{Statistical analysis}

The experiments were carried out in triplicate and the data obtained have been presented as mean \pm standard deviation. The obtained data were subjected to Analysis of Variance (ANOVA) using OP Stat software, for the analysis of commonly used experimental designs. The obtained data were interpreted at 5 per cent level of significance $(p \leq 0.05)$.

\section{Results and Discussion \\ 3.1 Chemical Analysis}

The Chemical composition of Pancakes depicted in Table 2 showed there was a significant difference in the moisture content of $\mathrm{PC}_{1}, \mathrm{PC}_{2}, \mathrm{PC}_{3}$, and $\mathrm{PC}_{4}$ as compared with $\mathrm{PC}_{0}$ (control). The moisture content was highest in $\mathrm{PC}_{2}$ (7.49) followed by $\mathrm{PC}_{3}$ (6.92), $\mathrm{PC}_{1}$ (6.35) and $\mathrm{PC}_{4}$ (6.30) where as $\mathrm{PC}_{0}$ (control) sample showed the lowest moisture content (4.93). An insignificant difference existed between the samples $\mathrm{PC}_{1}$ and $\mathrm{PC}_{4}$. However the difference was significant in case of $\mathrm{PC}_{2}$ sample when compared to the control $\left(\mathrm{PC}_{0}\right)$, $\mathrm{PC}_{1}, \mathrm{PC}_{3}, \mathrm{PC}_{4}$ respectively. A significant difference existed in the ash content of control when compared to all other samples. However the difference was non-significant between sample $\mathrm{PC}_{2}$ (2.84), $\mathrm{PC}_{4}$ (2.45), $\mathrm{PC}_{1}$ (3.04), $\mathrm{PC}_{3}$ (3.07). The highest ash content was recorded in the sample $\mathrm{PC}_{3}(3.07)$ whereas the lowest value was found in the control $\left(\mathrm{PC}_{0}\right)$ i.e. 1.57 followed by $\mathrm{PC}_{2}, \mathrm{PC}_{4}, \mathrm{PC}_{1}$ respectively. Protein content was significantly higher in the $\mathrm{PC}_{4}(16.28)$ when compared to all other sample including control, it was significantly lower in control (12.56). All the samples except $\mathrm{PC}_{1}$ and $\mathrm{PC}_{2}$ varied significantly amongst each other. The addition of field pea increased the ash, protein and fiber content in the formulations which indicates the health benefits of this amendment as increased ash content gives an index to the increased mineral content in the food material. The protein content was increased by increasing the amount of field pea which is likely to be helpful in combating malnutrition in children. Fat content was highest in the control (27.11) sample followed by $\mathrm{PC}_{4}, \mathrm{PC}_{3}, \mathrm{PC}_{1}$, and the lowest fat content was recorded in sample $\mathrm{PC}_{2}(13.44)$. There was significant variation in the fiber content of $\mathrm{PC}_{1}, \mathrm{PC}_{2}, \mathrm{PC}_{3}$ and $\mathrm{PC}_{4}$ when compared to $\mathrm{PC}_{0}$. The crude fiber content was found the highest in the sample $\mathrm{PC}_{4}$ (6.53) followed by $\mathrm{PC}_{3}$ (4.60), $\mathrm{PC}_{2}$ (3.39) $\mathrm{PC}_{1}$ (2.58) and the lowest was found in the control (1.05). The variation was found to be significant among all the samples when compared to the control. The increased fiber content showed positive health benefits for managing metabolic disorders. The carbohydrate content was significantly highest in the sample $\mathrm{PC}_{1}$ (55.67) when compared to all other samples, with the minimum value recorded in the sample $\mathrm{PC}_{4}$ (42.41). All samples except $\mathrm{PC}_{2}$ and $\mathrm{PC}_{0}$ varied significantly to each other. The energy content was highest in the $\mathrm{PC}_{0}(505.37)$ sample whereas the least energy content was found in sample $\mathrm{PC}_{3}$ (438.55). All the samples except $\mathrm{PC}_{2}$ and $\mathrm{PC}_{3}$ varied significantly to each other.

\subsection{Organoleptic Evaluation}

Table 3 represents the sensory evaluation of Pancakes prepared by field Pea and Besan. Different formulations were prepared with the use of different amounts of flour and 
Pancakes evaluated for sensory characteristics. The colour scores of $\mathrm{PC}_{0}$ (control) sample was highest (8.03) as compared to all other formulations. $\mathrm{PC}_{2}$ had maximum colour scores after control sample. However, no significant difference was recorded among the samples. The scores for flavor were found in the range of "like moderately" to "like very much". The flavor score for control $\left(\mathrm{PC}_{0}\right)$ was found to be highest as compared to other samples. Samples $\mathrm{PC}_{2}$ and $\mathrm{PC}_{3}$ were evaluated as equal (7.81) for flavor. Sample $\mathrm{PC}_{1}$ was found to have minimum acceptance for flavor as compare to the others, however the samples varied non-significantly.

The texture scores for Pancakes was highest in sample $\mathrm{PC}_{2}$ as compared to all other formulations as well as control (7.97), whereas the sample $\mathrm{PC}_{1}$ was scored minimum for texture. The difference between samples varied non-significantly. The scores for taste was highest in control $\left(\mathrm{PC}_{0}\right)$ i.e. 8.06 followed by sample $\mathrm{PC}_{3}(7.97)$, with the difference between samples being non-significant. Sample $\mathrm{PC}_{1}$ scored minimum score for taste (7.47). The overall acceptability of Pancakes was found highest in sample $\mathrm{PC}_{0}$ (control) followed by sample $\mathrm{PC}_{2}$ i.e 7.95 and 7.82 respectively. All samples were acceptable but varied non-significantly.

\section{Conclusion}

From the aforesaid discussion it is inferred that field pea flour can be used in the preparation of healthy and nutritious
Pancakes which found its acceptability not only with the consumers but at the same time nutritional value is also improved as the ash, protein and fiber content increased significantly with the use of field pea in the formulation.

\section{Acknowledgment}

The authors are thankful to UGC for granting scholarship for the conduction of research and Research Station Sangla (Himachal Pradesh), in providing the field pea for research purposes and the facilities provided by the Department of Food Science Nutrition and Technology, CSKHPKV, Palampur.

6. Conflict of Interest: The authors declare that they have no conflict of interest of any kind.

Table 1: Ingredients used in Formulations

\begin{tabular}{|c|c|c|c|c|c|}
\hline Ingredients & PC $_{\mathbf{0}}$ (Control) & PC $_{1}$ & PC $_{2}$ & PC $_{3}$ & PC $_{4}$ \\
\hline Besan (Gram flour) & $100 \mathrm{~g}$ & $75 \mathrm{~g}$ & $50 \mathrm{~g}$ & $25 \mathrm{~g}$ & - \\
\hline Field pea flour & - & $25 \mathrm{~g}$ & $50 \mathrm{~g}$ & $75 \mathrm{~g}$ & $100 \mathrm{~g}$ \\
\hline Salt & $5 \mathrm{~g}$ & $5 \mathrm{~g}$ & $5 \mathrm{~g}$ & $5 \mathrm{~g}$ & $5 \mathrm{~g}$ \\
\hline Green chilli & $5 \mathrm{~g}$ & $5 \mathrm{~g}$ & $5 \mathrm{~g}$ & $5 \mathrm{~g}$ & $5 \mathrm{~g}$ \\
\hline Turmeric & $2 \mathrm{~g}$ & $2 \mathrm{~g}$ & $2 \mathrm{~g}$ & $2 \mathrm{~g}$ & $2 \mathrm{~g}$ \\
\hline Oil & $10 \mathrm{ml}$ & $10 \mathrm{ml}$ & $10 \mathrm{ml}$ & $10 \mathrm{ml}$ & $10 \mathrm{ml}$ \\
\hline Water & $150 \mathrm{ml}$ & $150 \mathrm{ml}$ & $150 \mathrm{ml}$ & $150 \mathrm{ml}$ & $150 \mathrm{ml}$ \\
\hline
\end{tabular}

Table 2: Proximate composition of Pancakes

\begin{tabular}{|c|c|c|c|c|c|c|c|}
\hline $\begin{array}{l}\text { Parameters } \\
\text { Samples }\end{array}$ & Moisture (\%) & $\begin{array}{l}\text { Ash } \\
(\%)\end{array}$ & $\begin{array}{c}\text { Portein } \\
(\%)\end{array}$ & $\begin{array}{l}\text { Fat } \\
(\%)\end{array}$ & $\begin{array}{c}\text { Crude fiber } \\
(\%)\end{array}$ & $\begin{array}{c}\text { Carbohydrate } \\
(\%)\end{array}$ & $\begin{array}{c}\text { Energy } \\
(\text { Kcal/100 g) }\end{array}$ \\
\hline $\mathrm{PC}_{0}$ & $4.93 \pm 0.05$ & $1.57 \pm 0.08$ & $12.56 \pm 0.68$ & $27.11 \pm 0.25$ & $1.05 \pm 0.02$ & $52.79 \pm 0.68$ & $505.37 \pm 1.64$ \\
\hline $\mathrm{PC}_{1}$ & $6.35 \pm 0.13$ & $3.04 \pm 0.13$ & $13.99 \pm 0.32$ & $19.37 \pm 0.17$ & $2.58 \pm 0.07$ & $55.67 \pm 0.36$ & $448.96 \pm 0.58$ \\
\hline $\mathrm{PC}_{2}$ & $7.49 \pm 0.18$ & $2.84 \pm 0.02$ & $13.44 \pm 0.15$ & $13.18 \pm 0.15$ & $3.39 \pm 0.16$ & $53.66 \pm 0.51$ & $441.01 \pm 0.52$ \\
\hline $\mathrm{PC}_{3}$ & $6.92 \pm 0.39$ & $3.07 \pm 0.15$ & $14.79 \pm 0.13$ & $19.38 \pm 0.07$ & $4.60 \pm 0.03$ & $51.25 \pm 0.66$ & $438.55 \pm 0.95$ \\
\hline $\mathrm{PC}_{4}$ & $6.30 \pm 0.25$ & $2.95 \pm 0.19$ & $16.28 \pm 0.33$ & $25.53 \pm 0.40$ & $6.53 \pm 0.06$ & $42.41 \pm 0.23$ & $464.52 \pm 2.65$ \\
\hline $\mathrm{CD}(\mathrm{p} \leq 0.05)$ & 0.41 & 0.24 & 0.68 & 0.43 & 0.15 & 0.95 & 4.98 \\
\hline
\end{tabular}

Table 3: Sensory score of Pancakes

\begin{tabular}{|c|c|c|c|c|c|}
\hline Samples Parameters & Colour & Flavor & Texture & Taste & Overall acceptability \\
\hline $\mathrm{PC}_{0}$ & $8.03 \pm 0.94$ & $7.88 \pm 0.96$ & $7.81 \pm 0.91$ & $8.06 \pm 0.93$ & $7.95 \pm 0.80$ \\
\hline $\mathrm{PC}_{1}$ & $7.59 \pm 1.28$ & $7.34 \pm 0.85$ & $7.47 \pm 1.18$ & $7.47 \pm 0.99$ & $7.47 \pm 0.91$ \\
\hline $\mathrm{PC}_{2}$ & $7.69 \pm 1.00$ & $7.81 \pm 0.77$ & $7.97 \pm 0.69$ & $7.81 \pm 0.85$ & $7.82 \pm 0.74$ \\
\hline $\mathrm{PC}_{3}$ & $7.34 \pm 1.25$ & $7.81 \pm 0.68$ & $7.91 \pm 0.52$ & $7.97 \pm 0.78$ & $7.76 \pm 0.71$ \\
\hline $\mathrm{PC}_{4}$ & $7.63 \pm 0.94$ & $7.69 \pm 0.95$ & $7.94 \pm 0.77$ & $7.72 \pm 1.00$ & 0.84 \\
\hline $\mathrm{CD}(\mathrm{p} \leq 0.05)$ & 0.77 & 0.60 & 0.60 & 0.65 & 0.56 \\
\hline
\end{tabular}

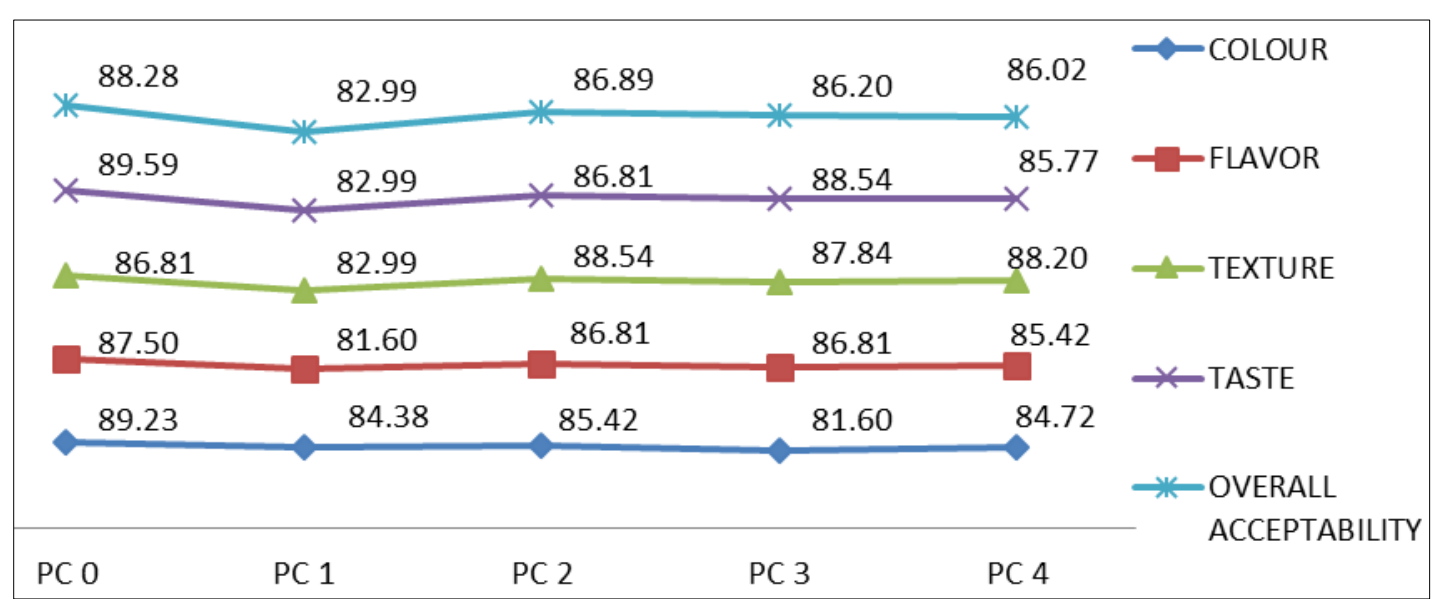

Fig 1: Index of Acceptance of Pancakes 


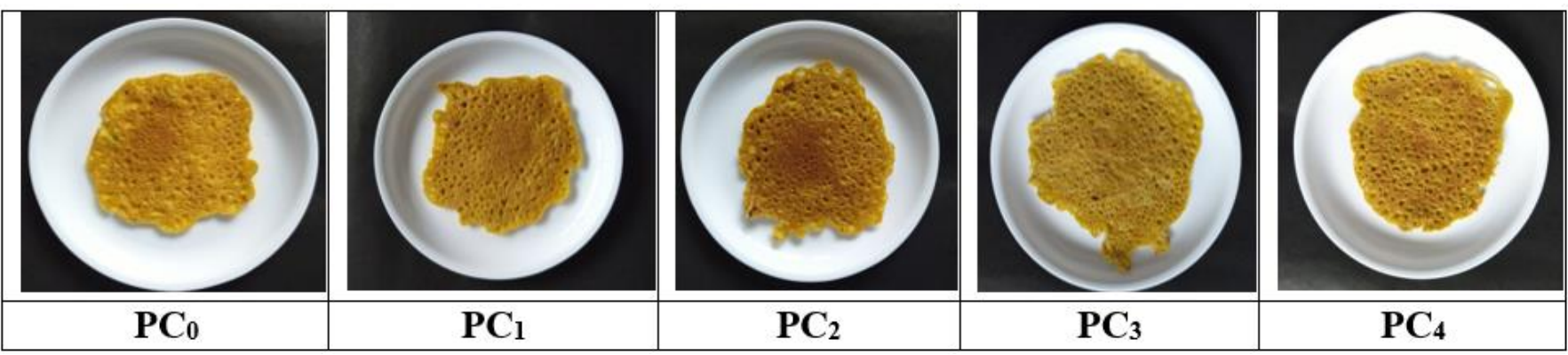

Fig 2: Physical appearance of Pancakes

\section{References}

1. AOAC. Official methods of analysis. Association of Official Analytical Chemist, Washington D.C.UK.14.068, 2057. 2010.

2. Bangladesh Bureau of Statistics (BBS). Yearbook of Agricultural Statistics-2015, 27th series, Statistics and Information Division, Ministry of Planning, Government of the people's Republic of Bangladesh 2016 Available at www.bbs.gov.bd

3. Chen C, Neill K, Burgess M, Bekkerman A. Agronomic benefit and economic potential of introducing fall-seeded pea and lentil into conventional wheat-based crop rotations. Agron. J 2012;104:215-224. doi:10.2134/agronj2011.0126.

4. Hood-Niefer SD, Warkentin TD, Chibbar RN, Vandenberg A, Tyler RT. Effect of genotype and environment on the concentrations of starch and protein in, and the physicochemical properties of starch from, field pea and faba bean. J. Sci. Food Agric 2012;92:141150. doi:10.1002/jsfa.4552.

5. Marinangeli CP, Jones PJ. Whole and fractionated yellow pea flours reduce fasting insulin and insulin resistance in hypercholesterolaemic and overweight human subjects. Brit J Nutr 2011;105:110-117.

6. Miller PR, Bekkerman A, Jones CA, Burgess MH, Holmes JA, Engel RE. Pea in rotation with wheat reduced uncertainty of economic returns in southwest Montana. Agron. J 2015;107:541-550. doi:10.2134/agronj14.0185.

7. Muramoto J, Smith RF, Shennan C, Klonsky KM, Leap J, Ruiz MS et al. Nitrogen contribution of legume/cereal mixed cover crops and organic fertilizers to an organic broccoli crop. Hort Science 2011;46:1154-1162.

8. Schumacher AB, Bradelli A, Macedo FC, Pieta L, Klug TV, Jong EV. Chemical and sensory evaluation of dark chocolate with addition of quinoa (Chenopodium quinoa Willd.). Journal of Food Science and Technology 2010;47:202-206.

9. Shevkani K, Singh N. Influence of kidney bean, field pea and amaranth protein isolates on the characteristics of starch-based gluten-free muffins. Int. J Food Sci Technol 2014;49:2237-2244.

10. Shevkani K, Singh N. Relationship between protein characteristics and film-forming properties of kidney bean, field pea and amaranth protein isolates. Int. J Food Sci Technol 2015;50:1033-1043.

11. Singh DK, Singh AK, Sanjay KS, Mandhata S, Srivastava OP. Effect of balanced nutrition on yield and nutrient uptake of pea (Pisum sativum L.) under IndoGangetic plains of India. The Bioscan 2015;10(3):12451249.

12. Wang N, Daun JK. Effect of variety and crude protein content on nutrients and certain antinutrients in field peas
(Pisum sativum L.). J Sci. Food Agric 2004;84:10211029. doi:10.1002/jsfa.1742. 